\title{
Analisis Kritis Atas Kebijakan Revaluasi Aset Kementerian Keuangan Tahun 2015
}

\author{
Sansaloni Butar Butar \\ Universitas Katolik Soegijapranata Semarang \\ email: sansaloni@unika.ac.id
}

\begin{abstract}
The objectives of the paper is to analyze critically the new regulation that was introduced in 22 October 2015. Indonesian government issued Regulation No. 191 / PMK.010 / 2015 aimed at getting companies to revalue their fixed asset. Under the new regulation, firms may take advantage of lower tax rate imposed on revaluation surplus.Minister of Finance believes that firm future performance will increasas the value of asset rises. The arguments go further by stating thatfirmthat has intention to offerstocks publicly for the first time would also find it beneficial. At the surface the arguments put forward by the government is quiet understandable. However, a deeper analysis shows these arguments are not based on a sound understanding of financial reporting proceduresgoverned by Indonesian Financial Accounting Statement. In summary, there are at least three fundamental weaknesses contained in the arguments: First, the government tends to forget the differences in the calculation of earnings (revenue) for tax purposes versus external reporting purposes, especially for investors and creditors. Second, equating the responsibility of private and public companies in terms of adhering to rules and standards. Third, Presuming that asset value alone determines the firms'future performance.
\end{abstract}

Keywords: Asset revaluation, operating performance, taxable income, financial reporting.

\begin{abstract}
Abstrak
Tulisan ini bertujuan untuk menganalisis secara kritis regulasi revaluasi aset yang dikeluarkan pemerintah tanggal 22 Oktober 2015. Pemerintah menerbitkan PMK No. 191/PMK.010/2015 yang diarahkan untuk mendorong perusahaan melakukan revaluasi aset. Regulasi yang baru ini menawarkan insentif pajak atas selisih nilai aset tercatat dan harga pasarnya pasca revaluasi. Menteri keuangan percaya bahwa dengan menaikkan nilai aset sesuai harga pasarnya akan meningkatkan kinerja perusahaan. Alasannya, dengan nilai aset yang tinggi, kemampuan perusahaan untuk mendapatkan kredit akan meningkat dan akan mendorong kinerja perusahaan di masa mendatang. Selain itu, perusahaan yang sedang mempertimbangkan untuk melakukan IPO akan diuntungkan karena memiliki nilai aset yang lebih tinggi. Sepintas argumen-argumen yang dikemukakan oleh pemerintah memang dapat dimengerti. Namun analisis yang lebih mendalam menunjukkan argumen-argumen itu tidak didasari pemahaman yang benar tentang prosedur pelaporan keuangan yang diatur dalam PSAK. Argumen yang dikemukakan juga cenderung menyederhanakan faktor-faktor yang mempengaruhi kinerja operasi di masa mendatang. Setidaknya ada tiga kelemaham mendasar: pertama, pemerintah cenderung melupakan perbedaan perhitungan pendapatan (laba) untuk tujuan pajak dan untuk pelaporan keuangan eksternal, khususnya ditujukan bagi investor dan kreditor. Kedua, menyamakan tanggung jawab perusahan privat dan publik dalam ketaatan terhadap peraturan. Ketiga, anggapan bahwa aset menentukan kinerja perusahaan.
\end{abstract}

Kata Kunci: revaluasi aset, kinerja operasi, laba kena pajak, pelaporan keuangan 


\section{PENDAHULUAN}

Tingkat pertumbuhan ekonomi dan target pemasukan pajakpada tahun 2015 yang tidak sesuai harapantelah mendorong pemerintah mengeluarkan Peraturan Menteri Keuangan (PMK) No. 191/PMK.010/2015 pada tanggal 22 Oktober 2015 menggantikan PMK No. 79/PMK.03/2008 yang lama. Paket kebijakan ini diambil dalam rangka meningkatkan pendapatan pajak dan mendorong pertumbuhan ekonomi. Peraturan lama yang ditetapkan pada tahun 2008 mewajibkan setiap entitas bisnis membayar $10 \%$ pajak final atas perbedaan nilai aset setelah revaluasi dipandang sebagai batu sandungan bagi perusahaan untuk melakukan revaluasi aset.

MelaluiPeraturan Menteri Keuangan (PMK) No. 191/PMK.010/2015yang baru, pemerintah menetapkan tarif pajak revaluasi aset bervariasi dari 3\% hingga 6\%. Lebih spesifik, perusahaan yang melakukan revaluasi aset tetap pada akhir tahun 2015 dan telah memperoleh penetapan penilaian kembali aset tetap dari kantor jasa penilai publik serta melunasi pajak penghasilan sampai dengan 31 Desember 2015 akan dikenakan tarif pajak 3\%. Sementara perusahaan yang melakukan revaluasi aset dari tanggal 1 januari 2016 sampai dengan tanggal 30 Juni 2016 dikenakan tarif pajak $4 \%$ dan yang melakukan revaluasi aset dari tanggal 1 Juli 2016 hingga 31 Desember
2016 dikenakan tarif pajak 6\%. Setelah tahun 2016, tarif pajak kembali seperti semula yaitu $10 \%$.

Menurut menteri keuangan, revaluasi penting dilakukan agar posisi keuangan (neraca) perusahaan menjadi lebih baik. Perusahaan berpeluang untuk mendapatkan tambahan modal yang lebih besarkarena memiliki posisi keuangan yang lebih baik. Hal ini akan berdampak positif pada kinerja operasional di masa mendatang. Pendapat menteri keuangan tersebut jelas sekali menyederhanakan prosedur pemberikan kredit yang dilakukan institusi keuangan. Persetujuan kredit harus melalui proses yang ketat dalam rangka menilai risiko kegagalan pembayaran utang (default risk).

Selain itu, asumsi bahwa neraca menjadi baik pasca revaluasi juga patut dipertanyakan. Perlu dicatat bahwa penyusunan laporan keuangan perusahaan publik tunduk pada standar akuntansi yang ditetapkan Dewan Standar Akuntansi Keuangan IAI bukan pada ketentuan pajak. Pendapat bahwa neraca perusahaan akan menjadi lebih baik setelah revaluasi mengisyaratkanbahwa perusahaan yang melakukanrevaluasi aset untuk tujuan perpajakan (buku pajak), juga melakukan revaluasi aset untuk tujuan pelaporan keuangan (buku komersial). Padahal menurut ketua Dewan Standar Akuntansi Keuangan Djohan Pinnarwan dalam suatu 
seminar memperingati 58 tahun IAI tanggal

16 November 2015, perusahaan boleh memilih untuk melakukan revaluasi aset dalam buku komersial atau hanya dalam buku pajak.

Menurut Djohan, selama ini ada salah kaprah yang berkembang di masyarakat bahwa revaluasi aset harus dilakukan secara bersamaan pada kedua buku. Selain pernyataan Menteri Keuangan, salah kaprah juga terindikasi dari pernyataan yang disampaikan Menteri Koordinator Maritim dan Sumber Daya Rizal Ramli dalam suatu kesempatan di hadapan wartawan beberapa saat sebelum peraturan baru diterbitkan tanggal 22 Oktober 2015. Menurut beliau, revaluasi aset akan meningkatkan nilai aset perusahaan hingga berkali lipat dan berbekal modal yang kuat perusahaan akan mendapatkan dana segar melalui penawaran saham perdana (IPO) dan juga pinjaman bank.Pernyataan Rizal Ramli mengandung arti bahwa revaluasi aset dilakukan secara bersamaan untuk tujuan pajak dan tujuan akuntansi. Inilah yang dimaksud ketua Dewan Standar Akuntansi Keuangan Djohan Pinnarwan sebagai salah kaprah dan diperkuat oleh pernyataan salah satu anggota Dewan Pengurus Nasional IAI Rosita Uli Sinaga bahwa revaluasi aset berdasarkan perpajakan berbeda dengan revaluasi berdasarkan akuntansi.
Tulisan ini menganalisis secara kritis salah kaprah yang terkandung dalam argumen pemerintah yang mendorong perusahaan melakukan revaluasi aset. Di samping itu, tulisan ini juga akan mengkritisi pendapat yang mengaitkan revaluasi aset dengan kinerja perusahaan. Pertama-tama dipaparkan dulu tentang standar akuntansi keuangan yang mengatur profesi akuntansi di Indonesia dan perbedaan aturan antara buku komersial dan buku pajak. Setelah itu akan dibahas perbedaan pengakuan transaksi berdasarkan aturan akuntansi dan pajak. Bagian akhir tulisan akan mengkritisi klaim pemerintah bahwa revaluasi aset meningkatkan kinerja operasional di masa depan.

\section{PSAK Sebagai Pedoman}

Laporan keuangan perusahaan diarahkan terutama untuk kepentingan para investor dan kreditor. Investor membutuhkan informasi relevan yang dapat membantu mereka menilai kapasitas perusahaan menghasilkan aliran kas di masa depan. Sementara bagi kreditor, laporan keuangan berguna untuk menilai kelayakan kredit. Đengan melakukan analisis terhadap likuiditas, solvabilitas, dan profitabilitas kreditor mengestimasi kemampuan debitur mengembalikan utang. Keandalan laporan keuangan dalam membantu investor dan kreditor mengambil keputusan bisnis sangat 
ditentukan oleh ditentukan oleh penerapan prosedur pengukuran dan pengakuan yang sehat.

Pengukuran dan pengakuan merupakan aktivitas paling sentral dalam akuntansi. Sebagian besar waktu akuntan tercurah pada proses ini. Tidak hanya mengukur peristiwa yang benar-benar telah terjadi, akuntan juga harus menilai atau mengestimasi kemungkinan-kemungkinan peristiwa akan datang mempengaruhi sumber daya perusahaan. Transaksi yang kompleks dan membutuhkan pertimbangan profesional yang mendalam sering menjadi penghalang dalam pelaksanaan tugas akuntan. Hal ini terasa semakin rumit karena akuntansi tidak memiliki hukum-hukum yang dapat digunakan secara logis dalam menjastifikasi aktivitas pengukuran dan pengakuan yang mereka lakukan. Akuntansi tidak mengenal yang namanya hukum sebab-akibat. Kesalahan dalam mengestimasi menjadi sulit terhindarkan dan bisa menurunkan kualitas laporan keuangan yang dilaporkan perusahaan.

Sebenarnya profesi akuntansi telah berupaya untuk mengembangkan teori akuntansi yang dapat digunakan sebagai dasar dalam menjelaskan fenomena akuntansi dan membantu mengembangkan akuntansi di masa mendatang. Namun hingga saat ini tidak ada satu teori yang dapat menjelaskan seluruh aspek akuntansi secara memuaskan. Teori akuntansi yang ada saat ini merupakan kumpulan dari konsep, prinsip, asumsi, dan pemikiran logis lainnya yang dirasakan bermanfaat untuk menjelaskan aktivitas yang dilakukan oleh para akuntan (Wolk et al. 2009). Berbeda dengan ilmu alam, kebenaran dalam akuntansi tidak bersifat mutlak tetapi hanya bersifat relatif sesuai dengan lingkungan yang melingkupinya. Oleh karena itu, profesi akuntansi memandang penting untuk menetapkan standar pelaporan keuangan sebagai pedoman kerja akuntan agar laporan keuangan yang dihasilkan dapat diperbandingkan.

Walaupun akan dibahas lebih detail pada subseksi berikutnya, harus dipahami bahwa ada perbedaaan mendasar antara sistem pencatatan yang diadopsi dalam akuntansi dan sistem pencatatan yang diakui perpajakan sebagai dasar perhitungan pendapatan. Prosedur penilaian dan pengakuan yang dijalankan perusahaan terbuka (publik) di Indonesia harus tunduk pada standar akuntansi keuangan yang ditetapkan dewan standar yang dikenal dengan Pernyataan Standar Akuntansi Keuangan (PSAK). Sementara, aparatur pajak memiliki aturan sendiri sebagai dasar perhitungan pendapatan (laba) kenapajakdan berlaku untuk perusahaan publik dan perusahaan privat (perseorangan). 
Perlakuan akuntansi berdasarkan PSAK dan ketentuan pajak tidak konsisten satu dengan lainnya. Namun, perbedaan tersebut tidak perlu ditanggapi secara negatif karena keduanya memiliki tujuan yang berbeda. Standar akuntansi keuangan bertujuan agar komparabilitas laporan keuangan menjadi mungkin dilakukan. Sementara, ketentuan pajak hanya berfokus pada perhitungan pendapatan kena pajak. Jadi, sasaran yang hendak dituju antara akuntansi dan pajak berbeda secara substansi.

\section{Buku Komersial Versus Buku Pajak}

Perbedaan paling mendasar antara pembukuan perusahaan untuk tujuan komersial (commercial book) dan tujuan pajak (tax book) terletak pada prosedur pengakuan pendapatan dan biaya. Akuntansi menganut sistem akrual yang yang mengharuskan pendapatan atau biaya dicatat dalam buku perusahaan walaupun kas belum diterima. Sementara pajak menganut sistem kas yang hanya mengakui pendapatan atau biaya jika kas telah benar-benar diterima. Perbedaan dalam konsep pengakuan pendapatan tersebut menyebabkan perhitungan pendapatan kena pajak (taxable income) menjadi tidak sama antara akuntansi dan pajak. Dalam perspektif perpajakan, pada saat perusahaan telah menerima pembayaran, pendapatan yang dikenakan pajak (taxable income) akan bertambah seketika. Tidak demikian dengan sistem akuntansi. Pencatatan dalam akuntansi mengharuskan perusahaan mengikuti asas penandingan (matching priciple), dimana setiap pendapatan harus ditandingkan dengan biaya yang dikeluarkan dalam rangka memperoleh pendapatan tersebut, tanpa harus mempertimbangkan apakah kas telah diterima atau belum.

Penerapan kebijakan depresiasi yang berbeda antara akuntansi dan pajak juga dapat menyebabkan terjadinya perbedaan penghitungan pendapatan (laba) yang bersifat sementara (temporer).Kita ambil depresiasi sebagai ilustrasi. Standar akuntansi yang berlaku saat ini mengijinkan perusahaan-perusahaan memilih salah satu metoda depresiasi dari beberapa metoda depresiasi yang ada seperti metoda garis lurus, saldo menurun, dan lain-lain, tanpa memandang kelompok asetnya. Profesi akuntansi mengijinkan metoda depresiasi yang beragam bukan tanpa alasan. Perusahaan diharapkan memilih metoda depresiasi yang paling merefleksikan tipe aset dan pola pemakaian aset. Namun sering kali perusahaan menetapkan metoda depresiasi dan umur ekonomis aset berdasarkan kepentingan jangka pendek saja, misalnya menaikkan laba berjalan agar bonus tercapai. Di sisi lain, aturan perpajakan hanya mengijinkan perusahaan 
memilih metoda garis lurus atau saldo menurun. Metoda saldo menurun hanya boleh digunakan untuk kelompok bangunan saja. Jadi, fleksibilitas dalam memilih metoda depresiasi membuka peluang terjadinya perbedaan dalam pemilihan metoda depresiasi antara akuntani dan pajak. Misalnya, untuk tujuan akuntansi perusahaan memilih metoda garis lurustetapi untuk tujuan perpajakan memilih metoda saldo menurun.

Di samping pemilihan metoda depresiasi, pengelompokkan aset juga berbeda di antara keduanya. Akuntansi hanya mengelompokkan aset tetap ke dalam aset berwujud dan tidak berwujud dan mempersilahkan perusahaan menggunakan diskresi untuk menentukan tingkat depresiasi yang akan digunakan. Sementara menurut Undang-Undang No. 36 tahun 2008, aset dapat dikategorikan ke dalam empat kelompok. Tingkat depresiasi diatur berdasarkan kelompok aset sebagai berikut: untuk kelompok aset berwujud bukan bangunan dibagi ke dalam empat kelompok: kelompok 1 dibebankan 25\% per tahun selama empat tahun, kelompok 2 dibebankan 12,5\% selama 8 tahun, kelompok 3 dibebankan 6,25\% selama 16 tahun, dan kelompok 4 dibebankan 5\% per tahun selama 20 tahun.Untuk aset berwujud berupa bangunan yang bersifat permanen ditetapkan memiliki masa manfaat 20 tahun, dan bangunan tidak permanen memiliki masa manfaat maksimum 10 tahun.

Inkonsistensi pengakuan pendapatan dan biaya antara aturan pajak dan akuntansi menyebabkan terjadinya situasi yang dalam akuntansi disebut dengan perbedaan temporer (temporary differences) dan perbedaan permanen (permanent differences). Sesuai dengan frasa yang digunakan, perbedaan temporer akan hilang dengan sendirinya karena sifatnya sementara dan akan mengalami reversal di tahun-tahun mendatang. Biaya depresiasi yang dibebankan perusahaan dalam menghitung laba bisa lebih tinggi atau lebih rendah dari biaya depresiasi yang dihitung berdasarkan aturan pajak. Perbedaan laba kena pajak dan laba akuntansi yang muncul dari penerapan kebijakan deperesiasi yang tidak samahanya bersifat sementara dan akan mengalami reversal di masa mendatang.

Penerapan konsep pengakuan pendapatan yang berbeda juga menimbulkan perbedaan temporer. Sebagai contoh, perusahaan menerima pendapatan sewa sebesar Rp 300 juta pada tanggal 1 Januari 2016 untuk sewa gedung selama tiga tahun. Konsep pengakuan akuntansi yang menetapkan bahwa pendapatan hanya boleh diakui jika sudah terhak (earned) mengharuskan perusahaan mengakui pendapatan sewa sebesar Rp 100 juta pada tahun 2016. Sisa pendapatan sewa Rp 200 
juta lagi diakui masing-masing sebesar Rp 100 juta tahun 2017, dan Rp 100 juta tahun 2018. Namun, ketentuan pajak yang berbasis kas memasukkan seluruh nilai pendapatan sewa Rp 300 juta sebagai pendapatan kena pajak untuk tahun 2016. Akibatnya laba kena pajak akan lebih tinggi Rp 200 juta dibandingkan laba sebelum pajak yang tercatat di laporan laba-rugi. Perbedaan tersebut akan mengalami reversal pada tahun 2017 dan 2018 dan laba kena pajak akan lebih rendah dari laba yang dilaporkan perusahaan. Jadi, dalam tiga tahun ke depan perbedaan tersebut akan menghilang.

Tidak seperti perbedaan temporer, perbedaan permanen hanya terjadi sekali pada tahun pajak tertentu dan tidak bisa hilang karena biaya-biaya yang masuk kategori ini tidak dapat dikurangkan dalam menghitung pajak pendapatan. Sebagai contoh, perusahan melakukan pelanggaran dalam aktivitas bisnisnya dan diharuskan membayar denda sebesar Rp 500 juta. Dalam buku perusahaan, dana yang dikeluarkan ini diakui sebagai biaya dan akan mengurangi laba sebelum pajak. Sementara aturan pajak tidak mengijinkan biaya ini dimasukkan sebagai pengurang laba. Akibatnya, laba kena pajak akan lebih tinggi daripada laba yang dilaporkan perusahaan. Selisih ini tidak akan hilang dan hanya terjadi pada tahun itu saja.

\section{Revaluasi AsetMenurut Akuntansi dan Pajak}

Banyak pihak yang tidak menyadari atau cenderung melupakan perbedaan mendasar antara penghitungan laba akuntansi berdasarkan PSAK dan perhitungan laba menurut ketentuan pajak. Bagi sebagian orang, perbedaan ini menimbulkan kebingungan dan ketidakpercayaan terhadap perusahaan yang melaporkan pajak dan sebagian lagi curiga pada aparat pajak yang bertugas di lapangan. Namun perlu dicatat bahwa standar akuntansi yang menjadi dasar dalam menyusun laporan keuangan merupakan produk profesi akuntansi yang disusun berdasarkan konsep-konsep akuntansi yang telah berevolusi selama ratusan tahun dan tidak mengalami perubahan yang signifikan sepanjang waktu. Sementara standar perpajakan atau lebih tepat aturan-aturan perpajakan merupakan produk dari kebijakan-kebijakan publik yang sarat dengan kepentingan ekonomi dan politik. Aturan-aturan perpajakan sering berubah menyesuaikan arah kebijakan ekonomi yang diambil pemerintah.Jadi kurang tepat apabila standar akuntansi yang berlaku disamakan dengan ketentuan perpajakan. Bayangkan apa yang terjadi terhadap kualitas laporan keuangan publik jika perlakuan akuntansi selalu berubah mengikuti ketentuan pajak. 
Menurut saudagaran (2009), sistem pelaporan keuangan yang diterapkan di berbagai negara dapat dikelompokkan menjadi dua: single reporting dan dual reporting system. Di negara-negara yang menerapkan single reporting, laba yang dilaporkan dalam laporan keuangan perusahaan sama dengan yang dilaporkan untuk tujuan pajak. Namun, Indonesia tidak satu-satunya negara yang menerapkan dual reporting. Amerika Serikat juga membolehkan perusahaan-perusahaan publik di sana untuk menghitung laba menurut aturan-aturan yang ditetapkan profesi akuntansi dan ketentuan pajak. Negaranegara Eropa pada umumnya tidak membedakan sistem pelaporan yang ditujukan untuk pemegang saham dan kreditur, dan yang ditujukan untuk tujuan perpajakan.Single reporting hanya tepat digunakan di negara-negara yang aturan pajaknya tidak cepat berubah.

Tata cara yang harus diikuti oleh perusahaan publik dalam melakukan revaluasi aset di Indonesia diatur dalam PSAK 16 (revisi 2011) yang merupakan adopsi dari IAS 16.Dalam PSAK 16 dinyatakan bahwa setelah harga perolehan aset dicatat untuk pertama kali perusahaan boleh memilih model biaya ataumodel revaluasi untuk mencatat nilai aset tetap.Namun perlu dicatat bahwa model yang dipilih harus dijalankan secara konsisten untuk seluruh aset tetap dalam kelompok yang sama. Sekali perusahaan memilih model biaya atau model revaluasi, maka selanjutnya harus menggunakan model tersebut.

Secara teknis pencatatan, model biaya terhitung sederhana dan tidak menimbulkan masalah konseptual yang rumit. Nilai buku aset merupakan hasil pengurangan nilai perolehan aset terhadap akumulasi depresiasi serta akumulasi rugi penurunan nilai, jika ada.Nilai aset tetap yang tercantum di neraca akan berkurang seiring dengan umur pemakaian. Bagaimana jika suatu saat perusahaan merasa nilai buku aset tidak lagi mencerminkan nilai pasar dan ingin menyesuaikannya, padahal sebelumnya perusahaan sudah memilih metoda kos?. Berdasarkan PSAK 16 tahun 2011,perusahaan dapat beralih dari model biaya ke model revaluasi dan dampak perubahan berlaku prospektif. .

Ada beberapa perbedaan mendasar revaluasi aset berdasarkan PSAK 16 dan ketentuan perpajakan. Berdasarkan peraturan pajak lama yang tertuang dalam PMK 79/PMK.03/2008 perusahaan hanya boleh melakukan revaluasi aset setelah lima tahun. Ini berarti bahwa perusahaan harus kembali menggunakan model biaya setelah melakukan revaluasi aset. Ketentuan ini berbeda dengan yang diatur dalam PSAK 16 yaitu bahwa revaluasi dilakukan secara 
regular menyesuaikan perubahan harga pasar aset yang bersifat material. Namun regulasi terbaru yang tertuang dalam PMK191/PMK.10/2015 mengijinkan perusahaan melakukan revaluasi aset walaupun belum melewati jangka waktu lima tahun terhitung sejak penilaian kembali aset tetap terakhir.

Berkaitan dengan jenis aset tetap yang direvaluasi, peraturan pajak yang lama mengharuskan revaluasi aset dilakukan untuk seluruh kelompok aset. Ketentuan ini hampir mirip dengan PSAK 16, kecuali bahwa revaluasi dilakukan terhadap kelompok aset yang sama. Sementara berdasarkan regulasi terbaru revaluasi aset boleh dilakukan pada sebagian atau seluruh aset berwujud. Perusahaan boleh memilih aset yang mengalami kenaikan saja yang direvaluasi, sementara yang mengalami penurunan tidak direvaluasi. Praktik seperti ini tidak mungkin dilakukan jika menggunakan PSAK 16. Misalnya perusahaan memiliki 10 bidang tanah di berbagai tempat yang berbeda. Tanah yang terletak ditempat yang strategis telah mengalami kenaikan nilai yang berkali lipat. Sebaliknya, ditempat yang kurang strategis nilai tanah yang dimiliki perusahaan telah mengalamai penurunan nilai yang sangat besar. Perusahaan tidak diperkenankan hanya merevaluasi tanah yang mengalami kenaikan saja tetapi juga harus merevaluasi tanah yang mengalami penurunan nilai.
Ada dua kemungkinan yang bisa terjadi dari aktivitas revaluasi aset: nilai aset meningkat karena nilai pasar lebih tinggi dari nilai buku dan kemungkinan kedua nilai aset menurun karena nilai pasar lebih kecil dari nilai buku. Menurut PSAK 16, selisih lebih nilai aset setelah revaluasi ditampung dalam perkiraan yang disebut dengan surplus revaluasi (revaluation surplus) dan langsung dikredit ke ekuitas. Apabila sebelumnya perusahaan pernah melakukan revaluasi aset dan mengalami penurunan nilai, maka saldo surplus yang ada harus dikurangkan terlebih dari saldo penurunan nilai tersebut, dan jika ada sisanya baru diakui sebagai surplus revaluasi. Sebaliknya, jika revaluasi yang dilakukan dalam periode berjalan mengakibatkan penurunan nilai, maka penurunan tersebut harus diakui dalam laporan laba-rugi. Apabila sebelumnya perusahaan memiliki saldo surplus revaluasi maka, penurunan nilai harus terlebih dulu di offset ke perkiraan surplus revaluasi dan sisanya baru diakui di perkiraan laba-rugi. Perlu diingat bahwa perusahaan yang memilih metoda revaluasiharus siap sedia mengalami situasi yang tidak menentu karena nilai aset akan berfluktuasi sesuai dengan perubahan harga pasar. Jadi, masalah akuntansi yang muncul dari penilaian aset menggunakan model revaluasi lebih kompleks dibandingkan model biaya. 


\section{PEMBAHASAN}

\section{Analisis Kebijakan Revaluasi Aset Kementrian Keuangan}

Setelah memaparkan perbedaan ketentuan akuntansi dan pajak terkait revaluasi aset tetap sekarang tiba saatnya untuk mengkritisi paket revaluasi aset yang ditawarkan oleh Kementerian Keuangan. Pembahasan dalam bagian ini menitikberatkan pada tiga hal: miskonsepsi tentang revaluasi aset, motivasi revaluasi aset bagi perusahaan privat dan publik, dan kinerja perusahaan setelah revaluasi.

\section{Miskonsepsi Revaluasi Aset}

Seperti telah disinggung pada bagian sebelumnya, prosedur penilaian yang harus ditempuh oleh perusahaan-perusahaan publik di Indonesia dalam hal revaluasi aset mengacu pada PSAK 16. Namun ada salah kaprah yang terjadi saat ini. Aparat pemerintah, wartawan, dan pengamat perpajakan menganggap bahwa perusahaan yang mengambil paket insentif pajak yang ditawarkan melalui revaluasi aset akan otomatis melakukan revaluasi dalam buku komersialnya. Đalam suatu konferensi pers di kantor Kementerian Keuangan tanggal 30 Desember 2016, menteri keuangan Bambang Brodjonegoro mengatakan:

"Revaluasi bukan hanya sisi penerimaan pajaknya tapi dari sisi perusahaan yang mengalami revaluasi mendapatkan tambahan nilai aset, tambahan modal, dan ujungnya mereka punya kemampuan meminjam lebih besar. Jadi mendorong perusahaan Indonesia untuk bisa lakukan ekspansi atau untuk investasi. Dampak ekonomi lebih penting daripada dampak penerimaan pajak"

Pernyataan yang hampir sama diulang lagi oleh menteri keuangan Bambang Brodjonegoro dalam suatu konferensi pers di Jakarta tanggal 11 Januari 2016 dengan mengatakan:

"Revaluasi itu bukan paksaan. Itu sifatnya suka rela, perusahaan pasti untung, bukan cash memang, tapi aset nambah, ekuitas nambah, kemampuan bayar utang juga nambah. Dia akan lakukan revaluasi dengan senang hati “.

Pernyataan yang pertama menteri Bambang Brodjonegoro dengan jelas mengatakan bahwa kemampuan perusahaan dalam mendapatkan pinjaman meningkat karena nilai aset mengalami peningkatan. Kalimat mengandung makna yang sama juga tersirat dalam pernyataan yang kedua yaitu revaluasi aset meningkatkan nilai aset dan ekuitas dan akhirnya meningkatkan kemampuan berutang perusahaan. Dari dua pernyataan tersebut, secara implisit beliau mengakui bahwa perusahaan yang melakukan revaluasi aset untuk mendapatkan insentif pajak, juga akan melakukan revaluasi aset dalam buku komersial. Mengapa? karena laporan keuangan yang menjadi syarat penting menilai kelayakan kredit merupakan produk akuntansi. Laporan keungan yang terdiri dari laporan laba-rugi, 
neraca, laporan arus kas, dan laporan perubahan ekuitas merupakan hasil dari penerapan PSAK yang ditetapkan oleh profesi akuntansi bukan oleh institusi perpajakan. Jadi, menteri keuangan cenderung melupakan bahwa perusahaanperusahaan yang memiliki akuntabilitas publik atau perusahaan terbuka harus tunduk pada aturan-aturan yang ditetapkan oleh profesi akuntansi terkait dengan pelaporan keuangan kepada pihak eksternal. Sebagai menteri keuangan beliaucenderung menyamakan antara perusahaan terbuka dan perusahaan privat.

Ketentuan pajak berkaitan dengan revaluasi aset berwujud berbeda dengan ketentuan yang diatur dalam PSAK 16. Seperti yang telah dijelaskan sebelumnya, revaluasi aset menurut akuntansi mengharuskan perusahaan melakukan revaluasi untuk semua kelompok aset. Perusahaan tidak boleh merevaluasi asetyang mengalami kenaikan saja. Praktik ilegal seperti ini disebut dengan cherry picking meminjam pernyataan ketua Dewan Standar Akuntansi Keuangan IAI Djohan Pinnarwan. Sementara menurut ketentuan revaluasi aset terbaru yang dikeluarkan pemerintah, perusahaan boleh merevaluasi sebagian dari aset tetap saja. Fleksibilitas yang ditawarkan oleh aturan perpajakan membuka peluang bagi perusahaan privat untuk meningkatkan kemampuan berutang (creditworthiness).
Namun tidak demikian dengan perusahaaan publik. Kewajiban untuk mematuhi PSAK 16 menurunkan minat perusahaan publik memanfaatkan insentif pajak yang ditawarkan. Memang perusahaan masih dapat menikmatinya dengan menyelenggarakan pembukuan yang terpisah. Namun, praktik seperti ini menambah kerumitan dalam menghitung pajak yang ditangguhkan (deferred tax) dan tentunya akan menambah biaya pembukuan. Jadi, asumsi bahwa perusahaan yang melakukan revaluasi aset untuk tujuan perpajakan akan melakukan revaluasi yang sama dalam buku komersial merupakan miskonsepsi.

Faktor lain yang menghalangi perusahaan publik melakukan revaluasi terhadap aset tetap terkait dengan konsistensi penerapan model penilaian. Berdasarkan PSAK 16, sekali perusahaan menggunakan model revaluasi aset maka secara regular harus melakukan revaluasi aset, setidaknya sampai ada perbedaan yang material antara nilai tercatat aset dengan nilai pasarnya.Prinsip yang berbeda diterapkan dalam aturan pajak. Perusahaan diperbolehkan untuk kembali ke metoda biaya setelah melakukan revaluasi aset.

Secara konseptual, tujuan profesi akuntansi mengijinkan model alternatif adalah agar perusahaan dapat memilih model yang paling sesuai menggambarkan 
karakteristik aset yang dimiliki. Hal ini penting agar relevansi laporan keuangan dapat dipertahankan. Perusahaan-perusahaan yang nilai pasar asetnya selalu mengalami kenaikan mengikuti perubahan kondisi pasar seharusnya menggunakan metoda revaluasi agar posisi keuangan (neraca) mencerminkan kondisi sesungguhnya dan tetap relevan dalam membantu investor mengambil keputusan bisnis. Namun jika nilai aset yang dimiliki perusahaan cenderung stabil sepanjang waktu maka sebaiknya memilih metoda kos. Jadi, pemilihan model penilaian aset sangat dipengaruhi karakteristik aset.

\section{Motivasi Revaluasi Aset}

Alasan yang sering dikemukakan agar perusahaan memanfaatkan insentif pajak yang ditawarkan pemerintah terkait dengan peningkatan kinerja operasional di masa depan. Argumennya, kemampuan perusahaan mendapatkan modal tambahan,baik melalui kredit perbankan atau melalui IPO, meningkat karena memiliki aset yang lebih besar. Logika berikutnya, dengan modal tambahan yang lebih besar perusahaan dapat melakukan ekspansi bisnis dan memiliki dana yang cukup untuk berinvestasi pada proyek-proyek yang menjanjikan keuntungan besar sehingga mendongkrak kinerja operasi perusahaan.

Sebelum membahas kelemahan argumen di atas, perlu dicatat bahwa keputusan pemberian kredit sangat ditentukan oleh kemampuan perusahaan mengembalikan pinjaman. Argumen yang mengaitkan jumlah aset dengan besaran pinjaman yang diperoleh tidak memiliki dasar yang kuat. Aset secara terpisah tidak memberikan gambaran yang lengkap tentang kondisi kesehatan perusahaan. Aset hanya mencerminkan besar kecilnya ukuran perusahaan. Tidak lebih dari itu.Agar dapat menilai risiko ketidakmampuan perusahaan mengembalikan kreditatau sering disebut default risk, jumlah aset harus ditandingkan dengan kewajiban yang dimiliki. Default risk perusahaan yang memiliki aset yang besar belum tentu lebih rendah daripada perusahaan dengan aset yang lebih kecil. Semua tergantung dari besarnya kewajiban yang harus dilunasi.

Kemampuan mengembalikan utang juga ditentukan oleh jumlah kas yang dimiliki. Masalahnya adalah jumlah kas yang dimiliki perusahaan tidak mengalami perubahan pasca revaluasi. Jika demikian, apakah nilai aset yang meningkat pasca revaluasi memberi indikasi tentang arus kas masa depan?. Tentu tidak sama sekali. Arus kas masa depan bergantung pada kemampuan perusahaan menciptakan laba. Perusahaan dengan daya melaba (earning power) yang tinggi berpotensi menghasilkan arus kas masa depan yang tinggi pula. Daya 
melaba tercermin dari rasioprofitabilitas, seperti ROA (laba bersih dibagi aset) atau ROE (laba bersih dibagi ekuitas). Ironinya adalah kenaikan nilai aset pasca revaluasiotomatis menurunkan rasio profitabilitas. Begitu kreditor mendapati bahwa profitabilitas menurun, mereka akan merasa enggan untuk mengucurkan utang yang lebih besar. Dengan demikian, kenaikan nilai aset tidak dengan sendirinya meningkatkan kemampuan perusahaan mendapatkan utangyang lebih besar.

Argumen lain yang dikemukakan untuk menjastifikasi revaluasi aset terkait dengan penjualan saham perdana (IPO). Logikanya adalah bahwa dengan jumlah aset yang tinggi maka saham perusahaan akan semakin diminati. Jika banyak investor yang berminat pada saham perusahaan, maka harga saham akan meningkat dan target perusahaan untuk mendapatkan dana yang besar tercapai pula. Logika seperti ini tidak tepat. Jumlah aset yang tinggi tidak menjamin keberhasilan perusahaan dalam menjual saham. Kinerja saham pada saat IPO lebih ditentukan oleh prospek perusahaan ke depan.Minat membeli saham semakin besar bila perusahaan mampu menyakinkan investor tentang prospek di masa depan. Karena itu penting bagi perusahaan memberikan sinyal kepada calon investor mengenaikemampuan perusahaan menghasilkan laba di masa mendatang.

Sinyal ini tidak tercermin dari aset yang dimilikitetapi lebih pada tren laba dan kecukupan kas operasi. Informasi yang terkandung laporan laba-rugi dan arus kas membantu investor menilai tingkat profitabilitas dan kemampuan perusahaan dalam mendanai proyek-proyek investasi di masa mendatang. Apabila perusahaan bisa menyakinkan calon investor bahwa perusahaan memiliki profitabilitas, likuiditas, dan kas yang cukup untuk mendanai operasional sehari-hari, maka investor dengan senang hati berdiri dalam antrian untuk membeli saham perusahaan. Jadi, kesediaan investor membeli saham perusahaan dengan harga yang tinggi bukan karena besarnya nilai aset yang dimiliki tetapi pada keyakinan bahwa perusahaan memiliki kinerja operasi yang bagus di masa depan.

Bursa Efek Indonesia menetapkan aturan yang mengharuskan perusahaan menyediakan laporan keuangan tiga tahun secara berturut-turut pada saat IPO. Tujuannya adalah agar calon investor dapat melakukan analisis time series. Revaluasi aset menyebabkan tren laba menjadi tidak menyakinkan karena nilai aset tetap yang lebih tinggi akan menaikkan biaya depresiasi dan akhirnya menekan laba.Tren laba yang tidak stabil memberi sinyal negatif kepada pelaku pasar sehingga harapan untuk 
mendapat dana yang besar dari IPO tidak terwujud.

Selain informasi keuangan, informasi non-keuangan juga memberikan gambaran tentang masa depan perusahaan. Berbagai variabel dapat digunakan untuk memprediksi kondisi perusahaan di masa yang akan datang, diantaranya dengan mengamati pangsa pasar, kualitas produk, loyalitas konsumen, jaringan pemasaran yang kuat serta tim manajemen yang solid. Sering kali kesuksesan perusahaan ditentukan oleh variabel-variabel kualitatif tersebut. Memiliki aset yang besar tidak ada gunanya jika tidak dapat dikelola dengan benar. Kepiawaian manajer dalam mengarahkan seluruh sumber daya yang dimiliki menjadi sangat penting untuk menjamin keberlangsungan perusahaan. Ada banyak contoh perusahaan-perusahaan besar yang mengalami kebangkrutan karena kalah bersaing dengan perusahaan-perusahaan lain yang lebih kecil. Salah satu penyebabnya adalah lambat dalam merespon peluang yang ada dan juga lambat dalam melakukan perubahan.

$$
\text { Pemerintah tampaknya hanya }
$$
memandang bahwa peningkatan kinerja menjadi satu-satunya motivasi dalam melakukan revaluasi aset. Mengacu pada studi-studi empiris yang dilakukan selama ini, meningkatkan kemampuan utang dalam rangka menunjang kinerja operasional hanya satu dari banyak faktor yang mendorong perusahaan melakukan revaluasi aset. Brown et al., (1992) menemukan bahwa perusahaan melakukan revaluasi aset untuk menghindari hostile takeover. Beneish dan Press (1995) melaporkan bahwa revaluasi aset dilakukan perusahaan dalam rangka menghindar dari pelanggaran kontrak utang yang dapat berakibat pada penyitaan aset yang dijaminkan. Seng dan Su (2010) memberikan bukti bahwa revaluasi aset dilakukan manajer untuk memenuhi target-target pribadi atau perusahaan. Peneliti lain melaporkan revaluasi aset digunakan sebagai sarana pensinyalan (Jaggi dan Tsui,2001; Gaermynck dan Veugelers, 1999).

\section{Kinerja Setelah Revaluasi}

Pengalaman perusahaan yang pernah melakukan revaluasi aset dapat menjadi bahan refleksi menilai kemanfaatan revaluasi aset. Studi empiris mengenai hubungan antara kinerja di masa depan dengan revaluasi aset telah banyak dilakukan, diantaranya di Inggris, Australia dan Selandia baru. Umumnya studi-studi empiris dilakukan sebelum negara-negara tersebut mengadopsi IFRS 16 yang terbit tahun 2016 dan mengatur tentang revaluasi aset. Berdasarkan undang-undang perusahaan tahun 1985, Inggris mengijinkan perusahan melakukan revaluasi terhadap aset-aset yang memiliki umur panjang seperti tanah, 
bangunan, peralatan, dan pabrik. Namun tidak seperti IFRS 16 yang mewajibkan revaluasi untuk semua kelas aset, standar yang berlaku di Inggris pada saat itu mengijinkan perusahaan menggunakan diskresi dalam menentukan aset mana yang akan direvaluasi. Berbeda dengan Inggris, standar yang berlaku di Australia menyatakan bahwa jika perusahaan merevaluasi satu aset yang masuk dalam suatu kelompok (kelas) aset, maka aset-aset lain yang masuk dalam kelas tersebut harus direvaluasi. Praktik yang sama juga berlaku di Selandia Baru. Tampaknya IFRS 16 mengadopsi ketentuan revaluasi yang berlaku di Australia dan Selandia Baru. Berkaitan dengan frekwensi melakukan revaluasi, ketiga negara memiliki ketentuan yang hampir sama, yaitu revaluasi aset harus dilakukan secara regular jika nilai buku aset berbeda signifikan dengan nilai wajarnya.

Berbagai studi revaluasi aset yang dilakukandi Inggris, Australia dan Selandia Baru,fokus utamanya adalah menilai dampak revaluasi aset terhadap kinerja saham atau kinerja laba di masa mendatang. Proksi ukuran kinerja yang digunakan dalam penelitian-penelitian tersebut adalah harga saham/return saham (Easton et al. 1993; Barth dan Clinch, 1998) dan laba operasi di masa depan (Aboodyet al. 1999; Zhai 2007).

Penelitian empiris revaluasi aset yang dilakukan di Australia menemukan hasil yang tidak konklusif. Easton et al. (1993) melakukan pengujian empiris yang menghubungkan surplus revaluasi dengan harga dan return saham. Hasil penelitian menunjukkan hanya harga saham saja yang berkorelasi signifikan dengan surplus revaluasi. Mereka menginterpretasikan temuan ini sebagai bukti bahwa revaluasi aset yang dilakukan perusahaan-perusahaan di Australia memiliki kandungan informasi, walaupun tidak selalu tepat waktu.Ini berarti bahwa investor memandang revaluasi aset memiliki nilai. Barth dan Clinch (1998) menguji relevansi revaluasi aset yang dilakukan perusahaan-perusahaan di Australia dikaikan dengan harga saham dan beberapa variabellainyang mencerminkan nilai perusahaan. Menjadi fokus penelitian yaitu aset keuangan, aset berwujud dan aset tidak berwujud. Ketiga kelompok aset yang mengalami revaluasi, peneliti menemukan bukti kuat bahwa revaluasi yang dilakukan terhadap aset keuangan dan aset tidak berwujud memiliki kandungan informasi yang tinggi. Sementara, hasil pengujian terhadap aset berwujud menunjukkan hasil yang tidak konsisten.

Studi revaluasi aset yang dilakukan di Inggris pada awalnya lebih menekankan pada manfaat revaluasi aset dalam sudut pandang investor. Perubahan harga saham dan return saham pasca revaluasi mencerminkan penilaian investor terhadap kenaikan nilai 
aset serta ekspektasi kinerja di masa datang. Temuan-temuan dari studi awal ini mengindikasikan bahwa revaluasi aset tidak memiliki kandungan informasi. Namun, Bernard (1993) menyatakan pengujian berbasis reaksi pasar tidak memberikan bukti langsung mengenai hubungan revaluasi aset dan kinerja operasi di masa depan. Hubungan langsung dapat terindikasi dengan menghubungkan revaluasi aset dan kinerja laba di masa depan.

Riset Aboody et al. (1999) menguji hubungan antara revaluasi yang menaikkan nilai aset (upward revaluation) dengan kinerja operasi tiga tahun mendatang. Di samping itu, mereka juga menggunakan arus kas operasi dan laba operasi akuntansi. Hasil pengujian menunjukkan adanya hubungan signifikan antara revaluasi aset dan kinerja operasi dalam tiga tahun mendatang pasca revaluasi. Mereka juga menguji apakah surplus revaluasi (nilai pasar dikurangi nilai tercatat) memiliki kandungan informasi bagi pemegang saham. Hasil pengujian menunjukkan bahwa pasar merespon secara positif surplus revaluasi. Aboody et al. (1999)mengintepretasikan temuan yang menggunakan 5000 observasi perusahaan tersebut sebagai tanda bahwa revaluasi aset yang dilakukan di Inggris memiliki kandungan informasi. Dengan kata lain, revaluasi aset yang dilakukan di Inggris bertujuan untuk meningkatkan relevansi laporan keuangan dengan menampilkan secara wajar posisi keuangan perusahaan. Perubahan nilai pasar aset yang material dapat mendistorsi nilai aset tercatatdi neraca. Revaluasi dilakukan untuk mengembalikan aset pada nilai yang sebenarnya.

Zhai (2007) menggunakan data perusahaan-perusahaan Selandia Baru untuk menguji hubungan antara upward revaluation dan kinerja operasi masa mendatang. Hasil analisis regresi gagal menemukan hubungan signifikan revaluasi aset dengan kinera laba operasi satu tahun, dua tahun, dan tiga tahun. Hasil yang sama juga ditemukan menggunakan arus kas operasi. Perlu diketahui bahwa Selandia Baru telah mengadopsi IFRS 16. Item-item yang termasuk dalam kelompok peralatan, pabrik dan properti boleh direvaluasi sepanjang nilai wajarnya dapat ditentukan dan revaluasi harus dilakukan secara regular terhadap semua kelas aset. Berkaitan dengan penilaian pasar atas besaran revaluasi aset yang dilakukan perusahaan di Selandia Baru, Zhai (2007 ) menemukan bahwa revaluasi aset tidak mengandung informasi penting. Artinya, pasar tidak percaya bahwa dengan menaikkan nilai aset membawa pengaruh signifikan terhadap kinerja perusahaan di masa mendatang.

Untuk mendapat pemahaman yang lebih mendalam tentang hubungan revaluasi aset dengan kinerja di masa mendatang, hasil 
studi yang dilakukan di negara berkembang seperti Brasil penting untuk dicermati mengingat karakteristik ekonomi negara ini hampir sama dengan Indonesia. Hasil studi empiris yang dilakukan di negara ini sangat tepat sebagai bahan refleksi perusahaanperusahaan yang ada di Indonesia. Mengunakan sampel perusahan yang terdaftar di pasar modal Brasil, Lopes dan Walker (2012) menemukan bahwa revaluasi aset berhubungan negatif dengan kinerja masa depan dan tidak berhubungan dengan harga dan return saham. Hubungan negatif menunjukkan bahwa revaluasi aset justru menurunkan kinerja operasi perusahaan di masa mendatang. Di samping itu, mereka juga menemukan bahwa revaluasi aset berhubungan negatif dengan skor indeks tatakelola perusahaan. Berdasarkan temuantemuan tersebut, mereka menyimpulkan bahwa motivasi revaluasi aset tetap yang dilakukan perusahaan-perusahaan di Brasil lebih bersifat oportunistik daripada substantif.

Pengamatan terhadap hasi studi empiris dengan sampel perusahaan berasal dari negara-negara berbeda seperti yang dibahas di atas menunjukkan bahwa kemanfaatan revaluasi aset yang diklaim oleh pemerintah tidak didasarkan pada argumen yang kuat. Pemerintah seharusnya melakukan pengkajian yang lebih mendalam sebelum menelurkan kebijakan yang dapat dirasakan manfaatnya oleh perusahaan di masa depan. Kajian bisa dilakukan dengan mempelajari terlebih dahulu dampakdampak revaluasi aset terhadap kinerja perusahaan di negara-negara yang mengijinkan revaluasi aset jauh sebelum dilakukan di Indonesia. Perlu diingatkan bahwa para pelaku pasar modal adalah kumpulan orang-orang yang bertindak rasional dan tidak mudah percaya begitu saja pada kebijakan-kebijakanyang tidak berdampak signifikan pada masa depan perusahaan. Kebijakan revaluasi aset memang secara konseptual dapat meningkatkannilai aset dan kemampuan berutang perusahaan. Namun pasar tahu bahwa motivasi yang melatarbelakangi revaluasi aset bisa bermacam-macam, dari yang tulus hingga untuk mengelabui pemakai laporan keuangan. Satu hal yang pasti adalah bahwa revaluasi aset tidak menambah arus kas perusahaan. Pasar cukup rasional untuk membaca perubahanperubahan kebijakan akuntansi yang oportunistik. Perubahan kebijakan akuntansi yang hanya bersifat window-dressing tidak akan mendapat respon yang baik dari pasar. Pasar juga tampaknya mengetahui perusahaan-perusahaan mana yang bertujuan baik dan mana yang tidak. Revaluasi aset yang hanya bertujuan untuk meningkatkan ekuitas atau menurunkan leverage merupakan perilaku oportunistik untuk 
mengelabui pasar tentang kondisi perusahaan sesungguhnya. Dengan demikian, dorongan pemerintah agar perusahaan-perusahaan memanfaatkan insentif pajak yang ditawarkan dalam PMK No. 191/PMK.010/2015 harus disikapi dengan bijak

\section{SIMPULAN}

Kebijakan revaluasi aset yang dirilis Kementerian Keuangan tahun 2015 diarahkan untuk meningkatkan pemasukan pajak dan mendorong pertumbuhan ekonomi nasional. Aaturan baru, perusahaan hanya dikenakan pajak 3\% hingga 6\% atas selisih nilai pasar aset terhadap nilai tercatat. Tarif ini lebih murah dibandingkan tarif lama yang sebesar 10\%. Kementerian keuangan menyakini kebijakan tersebut juga akan membawa pengaruh positif terhadap kinerja perusahaan. Dengan nilai aset yang lebih tinggi, perusahaan lebih mudah untuk mendapatkan pendanaan eksternal, misalnya melalui utang dan IPO. Jumlah kredit yang diperoleh akan meningkat sesuai dengan nilai aset. Dengan kata lain, kemampuan mendapatkan dana eksternal menjadi semakin tinggi. Dengan tambahan modal ini perusahaan dapat menggarap proyek-proyek bisnis yang mendatangkan keuntungan. Di samping itu, nilai aset yang tinggi akan memudahkan perusahaan untuk menawarkan saham pada saat IPO. Investor akan tertarik untuk membeli saham perusahaan karena memiliki nilai aset yang besar. Demikian argumen-argumen yang dikemukakan oleh aparat pemerintah untuk menjastifikasi insetif pajak revaluasi aset yang ditawarkan.

Walaupun ada benarnya, argumenargumen di atas memiliki beberapa kelemahan yang mendasar. Setidaknya ada tiga kelemaham yang dapat dikemukakan: 1 . Miskonsepsi tentang proses penghitungan pendapatan (laba). 2. Mensejajarkan tanggung jawab perusahan privat dan publik. 3. Anggapan bahwa jumlah aset menentukan kinerja perusahaan. Pemerintah, dalam hal ini menteri keuangan, berasumsi bahwa perusahaan yang melakukan revaluasi aset untuk tujuan pajak, juga akan melakukannya untuk buku komersial. Persepsi seperti ini jelas tidak benar. Apabila hendak melakukan revaluasi aset dengan tujuan memperbaiki posisi keuangan (neraca), perusahaan publik di Indonesia harus tunduk pada PSAK 16 yang merupakan produk Dewan Standar Akuntansi Keuangan IAI bukan pada ketentuan pajak. Masalah muncul karena kedua aturan tersebut tidak konsisten satu dengan lainnya. Hal-hal yang tidak konsisten terkait dengan kelompok aset yang boleh direvaluasi dan metoda penilaian aset yang harus digunakan pasca revaluasi. Sulit bagi perusahaan publik untuk memanfaatkan insentif pajak yang ditawarkan mengingat dampak negatif yang ditimbulkannya 
terhadap laporan keuangan yang ditujukan untuk investor dan kreditor. Tidak demikian dengan perusahaan privat atau perorangan. Perusahaan privat dapat memanfaatkan insentif pajak dengan maksimal karena tidak memiliki tanggung jawab kepada pihak lain. Mereka tidak harus mematuhi metoda revaluasi yang diatur dalam PSAK. 16.

Kesuksesan perusahaan menawarkan saham pada saat IPO dipengaruhi oleh banyak faktor, baikfaktor keuangan dan nonkeuangan. Faktor keuangan diantaranya adalah laba, arus kas, dan aset yang dimiliki. Investor memerlukan informasi keuangan untuk mengestimasi kemampuan perusahaan mendatangkan kas masuk di masa depan. Kemampun mendatangkan arus kas di masa depan tercermin dari aktivitas operasi, aktivitas investasi, dan aktivitas pendanaan di masa mendatang. Informasi keuangan yang dibutuhkan untuk mengestimasi kemampuan menghasilkan arus kas masuk adalah laporan laba-rugi dan laporan arus kas.Sementara kombinasi aset dan kewajiban mencerminkan seberapa likuid perusahaan. Tinggi rendahnya aset yang dimiliki tidak memberi gambaran kepada investor atau kreditor tentang kemampuan perusahaan melunasi kewajibankewajibanjangka pendek (likuiditas) dan kewajiban jangka panjang (solvabilitas). Informasi tentang besaran aset saja tanpa dikaitkan dengan kewajiban tidak memiliki makna penting kecuali untuk mengklasifikasi perusahaan besar, sedang dan kecil. Agar bermakna, aset harus dikaitkan dengan kewajiban. Investor tidak akan tertarik untuk membeli saham perusahaan yang memiliki aset besar tetapi juga memiliki kewajiban besar dan yang tidak memberi prospek keuntungan yang menjanjikan. Jadi, pada saat IPO investor tidak cukup hanya melihat besaran aset saja tetapi harus dikombinasi dengan ukuran lain untuk menilai profitabilitas, likuiditas, dan solvabilitas

\section{DAFTAR PUSTAKA}

Aboody, D., M.E Barth, dan R. Kaznik. 1999. Revaluations of fixed asset and future performance: Evidence from UK. Journal of accounting and economics, Vol. 26, pp 149-178.

Barth, M.E, dan G Clinch. 1998.Revalued financial, tangible and intangible assets: associations with share prices and nonmarket based estimates. Journal of accounting research. Vol. 36. pp. 199233.

Beneish, M. D., dan E Press.1995. The resolution of technical default. The Accounting Review. Vol. 70. No. 2. pp. 337-353, 
Bernard, V.L.1993. Discussion of an investigation of revaluations of tangible long-lived assets.Journal of accounting research.Vol. 31.pp. 39-45.

Brown, P., H.Y Izan, dan A.L Loh. 1992. Fixed asset revaluation and managerial incentives. Abacus. Vol. 28. No. 1. pp. 36-57.

Easton, P.D., P.H Eddey, dan T.S Harris.1993. An investigation of revaluation of tangible long-lived assets. Journal of accounting research. Vol. 31. pp. 1-38 (supplement).

Gaermynck, A, dan R Veugelers. 1999. Revaluation of assets as a signalling device: a theoretical and empirical analysis. Accounting and business research. Vol. 29. No. 2, pp. 123-138.

Harianterbit. Com. 2015.Jurus rajawali bangkit 1: dengan revaluasi aset ekonomi tumbuh meroket. Diakses dari http://pembaca.harianterbit.com/daripem baca/2016/01/03/52142/58/27/SerialJurus-Rajawali-Bangkit-1-DenganRevaluasi-Aset-Ekonomi-TumbuhMeroket

Ikatan Akuntan Indonesia.2016. IAI dukung kebijakan pemerintah terkait revaluasi.Diakses dari http://www.iaiglobal.or.id/v02/berita/det ail.php?catid=\&id=864
Jaggi, B, dan J Tsui. 2001. Management motivation and market Assessment: revaluation of fixed Assets. Journal of international financial management and accounting. Vol. 12. No. 2. pp. 160-187.

Kompas. Com. 2015. Insentif PPh Revaluasi Aset, Pemerintah Bisa Mendapat Tambahan Penerimaan Rp 10 Triliun. Diakses

darihttp://bisniskeuangan.kompas.com/r ead/2015/10/23/095000126/Insentif.PPh. Revaluasi.Aset.Pemerintah.Bisa.Mendap at.Tambahan.Penerimaan.Rp.10.Triliun

Lopes, A.Bdan M. Walker. 2012. Asset revaluations, future firm performance and firm-level corporate governance arrangements: New evidence from Brazil. British accounting review.Vol. 44. No. 2. pp. 53-67

Rimanews. 2016. Menkeu minta penilai turunkan tarif jasa revaluasi. Diakses dari

http://ekonomi.rimanews.com/read/2016 0129/258734/Menkeu-Minta-PenilaiTurunkan-Tarif-Jasa-Revaluasi-

Saudagaran, S. M. 2009. International Accounting: A user perspective. A Wolters Kluwer business. CCH. 
Seng, D, and J Su. 2010. Managerial Zhai, Y.H. 2007. Asset revaluation and incentives behind fixed asset future firm operating performance: revaluations: evidence from New evidence from New Zealand. Working Zealand Firms. Working paper. Diakses paper. Diakses dari dari https://researcharchive.lincoln.ac.nz/bitst http://otago.ourarchive.ac.nz/bitstream/h ream/handle/10182/219/zhai_mcm.pdf andle/10523/1606/Seng_Fixed_Asset_R evaluations_-__submit_to_Illinoi.pdf .

Wolk, H.I., J.L Dodd, and J.J Rozycki. 2009. Accounting Theory: Conceptual Issues in a Political and Economic EnvironmentSeventh edition, Sage Publications. 